\title{
Biobanken i Den norske mor og barn undersøkelsen
}

\author{
Kjersti S. Rønningen ${ }^{1}$, Liv Paltiel ${ }^{1}$, Helle M. Meltzer ${ }^{2}$, Rannveig Nordhagen ${ }^{1}$, \\ Kari K. Lie ${ }^{1}$, Ragnhild Hovengen ${ }^{1}$, Margaretha Haugen ${ }^{2}$, Wenche Nystad ${ }^{1}$, \\ Jane A. Hoppin ${ }^{3}$ og Per Magnus ${ }^{1}$ \\ ${ }^{I}$ Divisjon for epidemiologi, Nasjonalt folkehelseinstitutt, Oslo \\ ${ }^{2}$ Divisjon for miljømedisin, Nasjonalt folkehelseinstitutt, Oslo \\ ${ }^{3}$ National Institute of Environmental Health Sciences, National Institutes of Health/DHHS, NC, USA \\ Korrespondanse: Kjersti S. Rønningen, Avdeling for arv og miljø, Divisjon for epidemiologi, Nasjonalt folkehelseinstitutt, \\ Postboks 4404 Nydalen, 0403 Oslo \\ Telefon: 22042302 Telefax: 22042351 E-post: kjersti.skjold.ronningen@fhi.no
}

\begin{abstract}
SAMMENDRAG
Biobanker for langtidslagring av biologisk materiale blir en viktigere og viktigere del av epidemiologiske studier. I planleggingen av en biobank er det en rekke avgjørelser som må tas for å sikre best mulig oppslutning både med hensyn til å få inn så mange prøver som mulig og å oppnå best mulig prøvekvalitet både på kort og lang sikt. Den norske mor og barn undersøkelsen (MoBa) skal inkludere 100000 svangerskap og følge mor, far og barn i lang tid fremover. Innsamlingen av data startet i ett fylke i 1999, og omfatter i dag hele landet. Siden det tas blodprøver to ganger fra hver kvinne, blodprøve fra far og navlesnorsblod fra barna, betydde dette at Biobanken for MoBa måtte planlegges for å kunne motta og langtidslagre over 380000 prøvesett. Ved Biobanken ved Nasjonalt folkehelseinstitutt lagres fullblod, plasma, urin, DNA og spesialrør til senere RNA isolering. Rekruttering til MoBa foregår ved 52 av landets sykehus. Prøvene sendes per post til Biobanken ved Folkehelseinstituttet for prosessering. Per januar 2006 er over 200000 prøvesett lagret ved Biobanken. Denne artikkelen gir en kortfattet oversikt over oppbyggingen av Biobanken og logistikken knyttet til innsamlingen av biologisk materiale, fra blodet tappes til det er sikkert lagret og klart til å tas ut på et senere tidspunkt, kanskje mange år inn i fremtiden.
\end{abstract}

Rønningen KS, Paltiel L, Meltzer HM, Nordhagen R, Lie KK, Hovengen R, Haugen M, Nystad W, Hoppin JA, Magnus P. The Biobank in The Norwegian Mother and Child Cohort Study. Nor J Epidemiol 2006; 16 (1): 59-62.

\section{ENGLISH SUMMARY}

Long term storage of biological material is becoming a critical component of many epidemiological studies. In designing specimen repositories, efforts need to be made to balance future needs for samples with logistical constraints necessary to process and store samples in a timely fashion. The Norwegian Mother and Child Cohort Study was started in 1999 and aims at including 100,000 pregnancies, and will follow mother, father and child for many years to come. The Biobank was faced with the challenge to receive and store over 380,000 biological samples from pregnant women, their partners and their children for up to 100 years. Biological specimens include whole blood, plasma, DNA and urine. The samples are collected at 52 hospitals in all parts of Norway and are mailed to the central Biobank in Oslo for processing and long term storage. As of January 2006, over 200,000 sample sets have been collected and stored at the Biobank. Here we describe the current Biobank structure and present the logistics for sample handling from the drawing of blood in the hospitals till retrieval of samples many years into the future.

\section{BAKGRUNN}

Innsamling og lang tids lagring av biologisk materiale har etter hvert blitt en integrert og stadig viktigere del av epidemiologiske studier (1). Når longitudinelle studier som inkluderer biologiske materiale skal planlegges, må en ta stilling til både hvordan prøveinnsamling skal skje og hvordan prøvene skal lagres for å få best mulig kvalitet på mulige analyser i fremtiden (2-10). Kostnader, gjennomførbarhet, prøvetakingsvolum, hvordan prøvene skal håndteres ved Biobanken, lagring og uttak av materialet må vurderes.
Den norske mor og barn undersøkelsen (MoBa) er en landsomfattende prospektiv studie som startet i liten skala i 1999, og hvor rekruttering og innsamling av biologisk materiale planlegges fullført i løpet av 2008. Biologisk materiale skal samles inn fra kvinner og deres partnere i 100000 svangerskap, og det tas navlesnorsblod av barna (11). Dette vil resultere i omtrent 380000 unike prøvesett som skal langtidslagres. I tillegg til biologisk materiale bes mor om å fylle ut spørreskjemaer i 17., 22. og 30. svangerskapsuke, samt når barnet er 6 mnd., 18 mnd., 3 år og 7 år. Også fedre blir bedt om å fylle ut et spørreskjema ved ca. 17. svanger- 
skapsuke. Gravide kvinner rekrutteres til MoBa fra hele landet ved at ultralydlaboratoriene sender lister over kvinner som får time til rutine ultralydundersøkelse ved omtrent 17 . svangerskapsuke til Medisinsk fødselsregister. Kvinnene mottar deretter invitasjon til undersøkelsen per post. Hensikten med MoBa er å studere hvordan genetikk og miljøfaktorer i samspill påvirker fødselsutfall og barnets og mors senere helse. Spørreskjemaopplysninger og biologisk materiale samles inn prospektivt. DNA isoleres fra alle deltakere og det lagres plasma og urin for studier av effekter av miljøgifter under svangerskapet. For deltakere født etter mai 2005 er det også mulig å isolere RNA fra navlesnorsblod. Kombinasjonen av biologisk materiale og spørreskjemainformasjon sammen med muligheter for kobling til ulike helseregistre, gjør MoBa til en stor forskningsressurs. Problemstillinger som kan studeres spenner vidt, og omfatter betydningen av ulike miljøfaktorer, så vel som genetikk alene og interaksjon av genetikk og miljøfaktorer for svangerskapsutfall og for senere somatisk og psykisk sykdom hos mor og barn. Vi presenterer her innsamling, prosessering og lagring av biologisk materiale i Biobanken i MoBa.

\section{INNSAMLING AV PRØVER}

Rekrutteringen til MoBa startet med en pilot i ett fylke, og vi kunne derfor endre enkelte prosedyrer underveis.
Dessuten har vi foretatt en del utvidelser av prøvetakingen, som gjør oss i stand til å besvare flere problemstillinger.

\section{Svangerskapsprover av mor}

Helt fra starten i MoBa er det tatt blodprøve på to $7 \mathrm{ml}$ EDTA-rør av mor ved ultralyd-undersøkelsen. Takket være ekstern finansiering ble prøvetakingen fra og med 2002 utvidet med enda to blodprøverør og en urinprøve fra mor til analyse av miljøgifter, se figur 1 . Urinprøven blir innsamlet mens kvinnen er på ultralydlaboratoriet, direkte på et spesialglass, hvorfra $8 \mathrm{ml}$ blir overført til et transportglass. Transportglassene var initialt uten bakteriostatika for i minst mulig grad å interferere med senere måling av miljøgifter. Da det ikke uventet var bakterievekst $i$ de fleste glassene ved ankomst til Biobanken, ble det besluttet å benytte transportglass med klorheksidin. På forhånd var det vist at dette ikke interfererer med viktige analyser, som bestemmelse av ftalater og bisfenol (12). De ekstra rørene består av to EDTA-rør på $3 \mathrm{ml} \mathrm{og} 7 \mathrm{ml}$.

\section{Prover fra far}

To $7 \mathrm{ml}$ EDTA-rør tas av far når han er med til ultralydundersøkelsen.

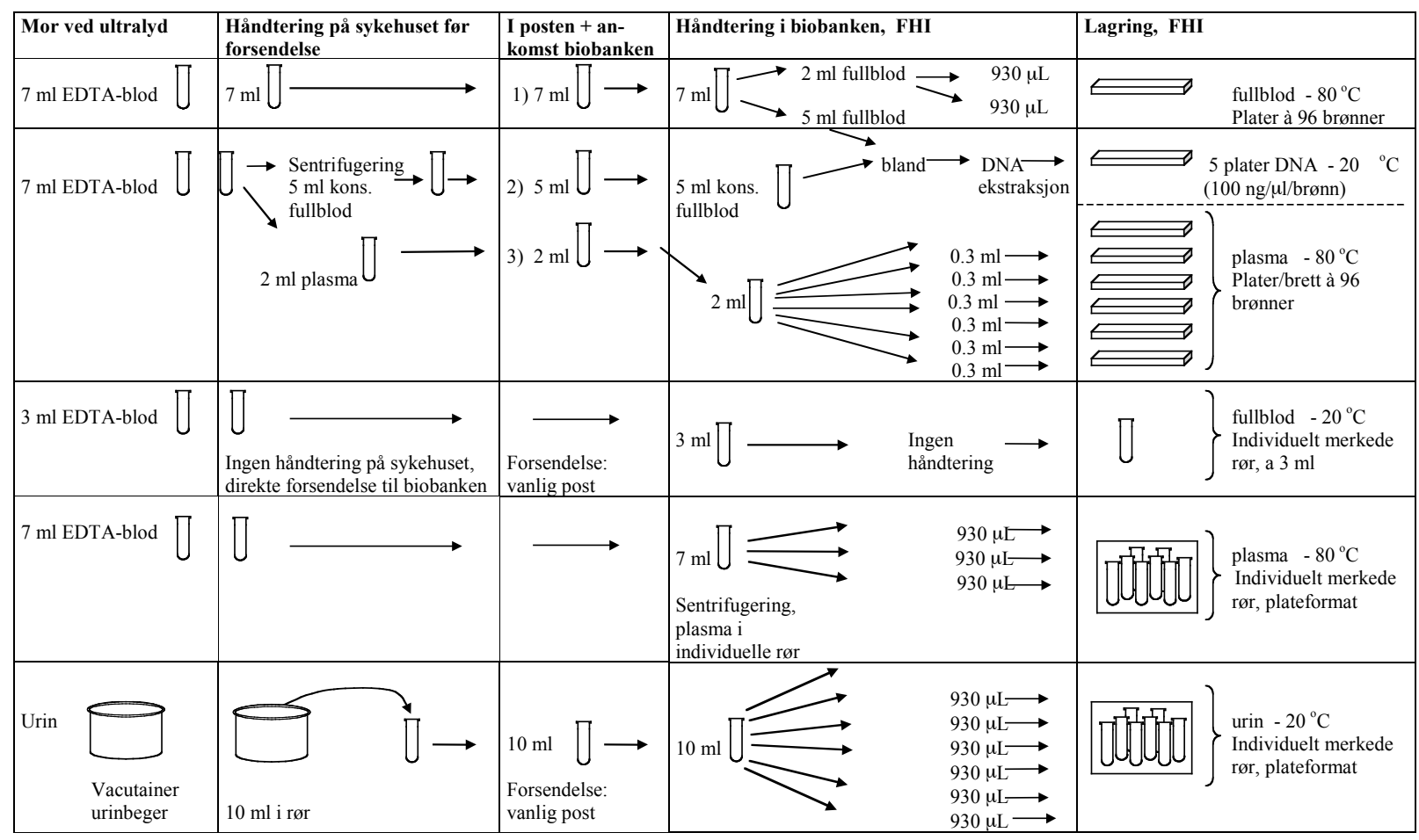

Figur 1. Blodprøvesettet som tas av kommende mødre ved 17. svangerskapsuke. Ved lokalt sykehus samles 3 stk 7 ml EDTA rør, 1 stk. $3 \mathrm{ml}$ EDTA samt urin. Det ene $7 \mathrm{ml}$ EDTA røret sentrifugeres ved lokalt sykehus og plasma avpipetteres, og overføres til nytt rør. Hele prøvesettet på 6 rør sendes til Biobanken ved Folkehelseinstituttet i Oslo med vanlig post. All prøvehåndtering ved Biobanken støttes av spesialdesignede dataprogrammer. Prøver alikvoteres på Tecan roboter. Fullblod, plasma og urin lagres ved -80 grader, plasma og fullblod til metallanalyser (3 ml EDTA rør) og DNA lagres ved -20 grader.

Fra mor ved fødsel og fra fedre samles det 2 stk. EDTA rør. Prøvehåndteringen er lik det som vises på denne figuren.

Fra navlesnor samles det $10 \mathrm{ml}$ EDTA (lagres som fullblod, plasma og DNA) og spesialrør for senere RNA isolering og genekspresjonsstudier (Tempus rør, som er tilsatt buffer med RNase inhibitor). 


\section{Navlesnorprover}

Fra starten i 1999 og frem til mai 2005 ble det tatt to 7 $\mathrm{ml}$ EDTA-rør fra barnets navlesnor etter fødselen. I mai 2005 ble dette endret til ett $10 \mathrm{ml}$ EDTA-rør og ett Tempus RNA-prøverør som inneholder buffer med RNase inhibitor. Med dette får vi fortsatt DNA og plasma og i tillegg har vi muligheten til å isolere RNA, som gir muligheter for å studere genekspresjon og å påvise eventuelle RNA-virus. Hvis det ikke blir tatt navlesnorsblod ved fødselen, blir det på noen sykehus tatt $0,5 \mathrm{ml}$ blod når blodprøver taes som en del av PKU-screeningen.

\section{Postpartum prover av mor}

Før mor forlater barselavdelingen tas blodprøver på to $7 \mathrm{ml}$ EDTA-rør. Det har ikke vært endring i denne prøvetakingen siden starten.

\section{Prosessering}

\section{Prosessering lokalt og forsendelse av biologiske prover}

Ved alle blodprøvetakingene, unntagen navlesnorprøvene, blir det ene EDTA-røret sentrifugert på sykehusene og $3 \mathrm{ml}$ plasma avpipettert til et separat glass. Alle prøvene sendes til Biobanken med vanlig post.

\section{Prosessering og registrering i Biobanken}

Prøvene blir vanligvis prosessert samme dag som de ankommer Biobanken, men prøver som ankommer lørdag blir satt i kjøleskap til mandag. Prosessering inkluderer registrering av informasjon i Biobankens dataprogram, sentrifugering og overføring av plasma fra navlesnorsblod og den ekstra $7 \mathrm{ml}$ blodprøven fra mor ved ultralyd, isolering av DNA, alikvotering og nedfrysning.

\section{Dataprogram for laboratorieinformasjon}

Et spesiallaget dataprogram, LIMS (Laboratory Information Management System) tar hånd om alle trinn $\mathrm{i}$ prosessen. I Biobanken blir persondata på prøveglassene erstattet med et generert biobanknummer, og barkoden som representerer biobanknummeret skrives ut til bruk i den videre prosesseringen. Ved hjelp av LIMS registreres videre prøvetype, dato ved ankomst, dato for prøvetaking, status for prøven (for eksempel hemolyse, koagulasjon) og så videre. Etter alikvotering blir også lagringsplass for alle alikvoter lagret i LIMS. Adgang til LIMS-programmet krever dobbel innlogging med to ulike brukernavn og passord. Databasen som inneholder opplysninger knyttet til laboratorienummeret er kryptert og atskilt fra databasen der laboratorienummeret kan knyttes til personidentifikasjon. Sikkerhetskopier av databasene tas hver natt, og oppbevares brannsikkert.

\section{Alikvotering}

Fullblod blir fordelt på to polypropylen plater $(930 \mu \mathrm{i}$ hver) og plasmaprøver som kommer fra sykehuslabo- ratoriene blir fordelt på seks polypropylen mikrotiterplater (300 $\mu 1$ i hver) ved hjelp av pipetteringsroboter. Platene blir forseglet ved hjelp av varmeforseglingsfolie. Miljøprøvene fra mødrene sentrifugeres ved Biobanken og plasma fordeles på tre individuelt merkede rør på tre Matrix ${ }^{\mathrm{TM}}$ plater (930 $\mu \mathrm{l}$ i hver). Urinprøvene blir fordelt på seks individuelt merkede rør $(930 \mu \mathrm{l}$ hver).

\section{DNA-ekstraksjon}

DNA blir isolert manuelt fra 8-12 $\mathrm{ml}$ blod ved hjelp av et FlexiGene kit. Før nedfrysning blir DNA-konsentrasjonen justert til $100 \mathrm{ng} / \mu 1$. DNA blir fordelt på 2-10 dypbrønnende plater (930 $\mu \mathrm{l}$ i hver) alt etter hvor mye DNA man kan få ekstrahert.

Alt biologisk materiale, unntatt blodet til DNAekstraksjonen, blir tatt hånd om og lagret samme dag som de registreres i Biobanken. Blod for DNAekstraksjon oppbevares ved romtemperatur til neste dag og blir da prosessert. Maksimum tid mellom blodprøvetaking og DNA-ekstraksjon er 5 dager.

\section{Lagring av prover}

Alt biologisk materiale blir lagret på plater med 96 brønners format unntatt $3 \mathrm{ml}$ EDTA rør og RNA rør. Plater som inneholder alikvoter fra samme prøve, blir lagret $\mathrm{i}$ to ulike frysere. $3 \mathrm{ml}$ EDTA-røret og Tempus RNA-røret lagres uåpnet ved ankomst til Biobanken ved respektive $-20^{\circ} \mathrm{C}$ og $-80^{\circ} \mathrm{C}$. Alle frysere er tilsluttet et eksternt alarmsystem, og koblet til et nødaggregat for back-up strøm.

\section{Uttak}

Det er nå planlagt flere forskningsprosjekter som skal bruke biologisk materiale fra MoBa. LIMS genererer lister over hvor de aktuelle prøvene gjenfinnes. Lokalisasjon av frysere og brett gjøres manuelt mens utpipetteringen av prøver automatiseres ved bruk av robot. Etter at prøvene er hentet frem vil mikroplater og prøverør settes tilbake på angjeldende langtids lagringsplass.

\section{Kvalitetskontroller}

$\AA$ foreta en så stor studie og over et så langt tidsrom fordrer et omfattende kontroll- og kvalitetsprogram. I tillegg til skriftlige standard prosedyrer som oppgraderes kontinuerlig, er nå et kvalitetssystem som tilfredsstiller kravene i NS-EN ISO 9001:2000 under utarbeidelse. Rutiner for blodprøvetaking, prosessering og lagring blir årlig kartlagt på de ulike sykehusene.

En oppfølging av hva som skjer med prøvene under prosessering og langtidslagring er en viktig del av kvalitetskontrollen, og en kontrollprøve blir derfor lagret på alle 96-brønners plater. For plasma og fullblod brukes $12,5 \%$ bovint serum albumin og for urinprøvene tas det med en steril vannprøve. For DNAprøvene brukes rehydreringsbufferen fra isolasjonskittet. Når det gjelder DNA, blir alle prøver kvalitetstestet med tanke på renhet ved å måle optisk densitet. 
Det er også med en negativ kontroll i alle sett à 24 prøver ved DNA-isolering som blir testet med tanke på DNA-forurensning.

Vi utfører også kontroll av endringer i ulike markører i plasma og urin under repeterte fryse-tine sykluser og ved langtidslagring. Natrium, kolesterol, triglyserider, frie fettsyrer, vitamin E og ASAT blir analysert i plasma og natrium og kreatinin i urin. Dette er viktig kvalitetstesting fordi henting av prøver vil innebære mange fryse-tine sykluser etter hvert.

\section{STATUS PER JANUAR 2006}

Fra en forsiktig start med tre inkluderte sykehus i 1999, er 52 sykehus med i studien i dag, se tabell 1. Undersøkelsen er landsdekkende og av de store sykehusene i Norge er det bare Rikshospitalet og Universitetssykehuset $\mathrm{i}$ Tromsø som ikke er med. Ved årsskiftet 2005/2006 er omtrent 65000 svangerskap inkludert. Disse utgjør $43 \%$ av alle som er invitert til å delta i studien. Når mor deltar, blir $80 \%$ av fedre med. Foreløpig er omtrent 50000 prøvesett mottatt fra de nyfødte barna.

MoBa er trolig det største forskningsprosjektet som noen gang er startet i dette landet. I 2005 ble det brukt
32 millioner kroner for å gjennomføre datainnsamlingen. Studien er en nasjonal dugnad, og utgiftene dekkes av offentlige norske forskningsmidler og av bevilgninger fra amerikanske og europeiske forskningsfond. Biobankmaterialet og spørreskjemadata vil i prinsippet være tilgjengelig for alle forskermiljøer etter søknad til Folkehelseinstituttet. Protokollen for undersøkelsen og retningslinjene for tilgang til data er tilgjengelig på www.fhi.no/morogbarn.

Tabell 1. Antall inkluderte sykehus i MoBa og antall prøvesett mottatt og registrert ved Biobanken (per 24.01.06).

\begin{tabular}{cccc}
\hline År & $\begin{array}{c}\text { Antall inklu- } \\
\text { derte sykehus }\end{array}$ & $\begin{array}{c}\text { Antall prøvesett } \\
\text { fra mor }\end{array}$ & $\begin{array}{c}\text { Antall prøvesett } \\
\text { totalt }\end{array}$ \\
\hline 1999 & 3 & 298 & 304 \\
2000 & 5 & 3122 & 4118 \\
2001 & 25 & 9514 & 15209 \\
2002 & 45 & 18100 & 32403 \\
2003 & 46 & 21650 & 41277 \\
2004 & 49 & 24755 & 47465 \\
2005 & 52 & 29165 & 56130 \\
2006 & 52 & 2021 & 4583 \\
Totalt & $\mathbf{5 2}$ & $\mathbf{1 0 8 6 2 5}$ & $\mathbf{2 0 1 4 8 9}$ \\
\hline
\end{tabular}

\section{REFERANSER}

1. Smith GD, Ebrahim S, Lewis S, Hansell AL, Palmer LJ, Burton PR. Genetic epidemiology and public health: hope, hype, and future prospects. Lancet 2005; 22: 1484-98.

2. Landi MT, Caporaso N. Sample collection, processing and storage. Review. IARC Sci Publ 1997; 142: 22336.

3. Gunter EW. Biological and environmental specimental banking at the Centers for Disease Control and Prevention. Review. Chemosphere 1997; 34:1945-53.

4. Ollier W, Sprosen T, Peakman T. UK Biobank: from concept to reality. Pharmacogenomics 2005; 6: 639-46.

5. Triendel R. Japan launches controversial Biobank project. Nature Med 2003; 9: 982-3.

6. Albertini RJ, Anderson D, Douglas GR, et al. IPCS quidelines for the monitoring of genotoxic effects of carcinogens in humans. International program on chemical safety. Mutat Res 2000; 463: 111-72.

7. Holland NT, Smith MT, Eskenazi B, Bastaki M. Biological sample collection and processing for molecular epidemiological studies. Mutat Res Rev 2003; 543: 217-34.

8. Eskenazi B, Bradman A, Gladstone E, et al. CHAMACOS, a longitudinal birth cohort study: lessions from the field. J Child Health 2003; 1: 3-27.

9. Holland NT, Pfleger L, Berger E, Ho A, Bastaki M. Molecular epidemiology biomarkers. Sample collection and processing considerations. Toxicol Appl Pharmacol 2005; 206: 261-8.

10. Eskenazi B, Gladstone EA, Berkowitz GS, et al. Methodological and logistic issues in conducting longitudinal birth cohort studies: Lessons learned from the Center for Children's Environmental Health and Disease Prevention Research. Environ Health Perspect 2005; 113: 1419-29.

11. Magnus P, Irgens LM, Haug K, Nystad W, Skjærven R, Stoltenberg C. The Norwegian Mother and Child Cohort Study (MoBa). Submitted, 2005.

12. Hoppin AJ, Ulmer R, Calafat AM, Barr DB, Baker SV, Meltzer HM, Rønningen KS. Impact of urine preservation methods and duration of storage on measured levels of environmental contaminants. J Expo Anal Environ Epidemiol (Epub ahead of print). PMID: 16007114, 2005. 